\title{
The Efficacy of Seluang Fish Oil (Rasbora agrotynea) Related Body Weight, Lipid Profile, Adiponectin and Leptin in High Fat Diet -Induced Wistar Rats
}

\author{
Fatmawati $^{1}$, Rachmat Hidayat ${ }^{2 \#}$, Erizka $^{3}$, Husnul Khotimah $^{4}$ \\ ${ }^{1}$ Department of Biochemistry, Faculty of Medicine, Universitas Sriwijaya \\ ${ }^{2}$ Biomolecular Laboratory, Faculty of Science, Universitas Sriwijaya \\ ${ }^{3}$ Departement og Micro Biology, Faculty of Medicine, Universitas Sriwijaya \\ ${ }^{4}$ Medical Student, Faculty of Medicine, Universitas Sriwijaya \\ \# Correspondence :dr.rachmat.hidayat@gmail.com \\ Received : February $7^{\text {th }} 2018$ \\ Accepted : March 19th 2018
}

\begin{abstract}
Background: Rasbora agrotynea (local name : Seluang ) is a fish native to Sumatera, Malaya and Borneo. This fish has a potential as a local wisdom for supplementation of omega 3 and omega 6. In Sumatera, Seluang fish was used as traditional food. The aim of this study to explore the efficacy of seluang fish oil in body weight, lipid profile, adiponectin and leptin level in Wistar Rats-Induced High Fat Diet.

Methods: This study was an experimental study, pre-post test with control group design. The sample in this study was 30 male rats, 8 weeks old, weight 150-200 gram. Rats were given high fat diet and seluang fish oil at dose of $0,1,0,2$ and $0,4 \mathrm{~mL} / 200 \mathrm{gr}$ BW/day for 2 weeks. Seluang fish oil was extracted by distilation methods. The results of this study were assayed by SPSS 18.

Results: Seluang fish oil $0,4 \mathrm{~mL} / 200 \mathrm{gr}$ BW was more potent to reduce body weight gain, triglyseride level, leptin and increase adiponectin level than seluang fish oil $0,1 \mathrm{~mL} / 200 \mathrm{gr} \mathrm{BW}, 0,2 \mathrm{~mL} / 200 \mathrm{gr} \mathrm{BW}$, negative control and positive control.

Conclusion: Seluang fish oil had a potention to reduce body weight, triglyceride, leptin and increase adiponectin level.
\end{abstract}

Keywords: Seluang fish Oil - body weight- triglyserida - leptin - adiponectin

\section{Background}

Obesity is a serious and complex health problem. This condition occurs due to dysregulation of several organ systems and dysregulated from molecular pathways, including the role of adipose tissue, liver, pancreas, gastrointestinal, nervous and genetic systems. A study shows that the condition of obesity will be associated with insulin resistance and serum adipokine status. Obesity conditions will lead to activation of adipokine production such as 
adiponectin, leptin, TNF alpha, MCP-1 and Il-6, which play a role in homeostasis, metabolism and inflammatory processes. ${ }^{1,2}$

Leptin plays a role in appetite regulation and regulation of body energy consumption. Increased leptin is caused by the occurrence of adipocyte hypertrophy and potentially disrupts the hypothalamus feedback and thus induces leptin resistance and contributes to the occurrence of hyperphagia and weight gain. ${ }^{3}$ Adiponectin is an adipokine produced by adipocyte cells, where adiponectin levels are found to be higher in the lean population than in the obese population. Adiponectin will reduce the occurrence of insulin resistance and triglyceride levels. Fatty acids, omega-3s, are potent fatty acids for prevention and management of obesity. Omega-3 is an essential fatty acid obtained from outside the body, because the body is unable to produce these fatty acids. There are two essential fatty acids, omega 3 and omega 6 . Omega 6 is represented by linoleic acid (LA) and omega 3 is represented by alpha-linoleic acid (ALA). LA will be metabolized to arachidonic acid (AA) and ALA will be metabolized to eicosapentaenoic acid (EPA) and docosahexaenoic acid (DHA). EPA and DHA are commonly found in fish oil . ${ }^{4}$

Omega 3 will reduce fat decomposition in adipose tissue by suppressing lipogenic enzymes and increasing $\beta$-oxidation. Studies show that EPA and DHA supplementation can prevent obesity, lose weight. Omega 3 will decrease the inflammatory response and decrease the production of prostaglandins and leukotriene, furthermore, will be followed by decreased cytokines TNF alpha and IL-6. Omega 3 also directly affects the expression of the PPAR gen gene, which plays a role in the process of adipogenesis, improves insulin sensitivity and energy restoration. Rasbora fish (Rasbora $\mathrm{sp}$ ) is endemic fish of south sumatera. The fish contains various vitamins and minerals that are beneficial to health. ${ }^{5}$ Previous studies have shown that fish extract contains high levels of vitamin D, omega 3, calcium and zinc. Therefore, this study was conducted to examine the role and effect of fish oil on the expression of protein regulators adipose metabolism, leptin and adiponectin, in obese rats model.

\section{Methods}

The research design was experimental study, pre-post test with control group design. The study had been approved by bioethic humaniora Faculty of Medicine Sriwijaya University.

\section{Preparation of Seluang Fish Oil}


Seluang fishes were collected from The Musi River Palembang, South Sumatera, Indonesia. Seluang fishes had been determined by Biology Laboratory, Faculty of Mathematics and Science, Sriwijaya University, South Sumatera, Indonesia. Seluang Fishes were washed and removed the feces from the gut. Boiling fish with wet randering method, where the milled fish is mixed with water at a ratio of 1:10. Next, the fish is cooked with a doubel jacket at temperature $90^{\circ} \mathrm{C}$ for 60 minutes. Fish oil located on the surface of thedecoction is separated.Subsequently, the filtered fish oil was subjected to cooling by storing in the coolant temperature $4^{\mathrm{O}} \mathrm{C}$ for 12 hours. The cooled oil will form three layers, the most basic layer is water, the second layer is free fatty acid and phosphatide and the top layer is fish oil.

\section{Procedure of Experimental}

Thirty rats were used in this study. Inclusion criteria were male Wistar Rats, eight weeks old, weight 150-200 gram and health. Rats were devided into 5 group, every group 6 rats. Rats were given high fat diet for 8 weeks. High fat diet contained $60 \%$ fat, $25 \%$ carbohydrate, $10 \%$ protein and 5\% vitamin and minerals. Every Rat was given high fat diet $10 \%$ from body weight. At the $9^{\text {th }}$ weeks, Rats were given high fat diet and treatment, group 1 : high fat diet + aquadest $1 \mathrm{~mL}$ (negative control), group $2:$ high fat diet + simvastatin 10 $\mathrm{mg} / \mathrm{kgBW}$ (positive control), group 3 : high fat diet + seluang fishoil0,1 mL/200 gr BW, group 4 : high fat diet + seluang fishoil0,2 $\mathrm{mL} / 200 \mathrm{gr} \mathrm{BW}$, and group 5: high fat diet+seluang fishoil0,4 mL/200 gr BW. Treatment was given for 2 weeks.

\section{The Body Weight, Lipid Profile, Adiponectin and Leptin Assays}

The body weight of rats were meassured before treatments and after treatments. It was used digital analytic scale (One Med). The meassurments was done three times and get the mean of body weight. Lipid profile (trigliseride level) was meassured using Spectrophotometer and Diasys Kits for trigliseride. Leptin and adiponectin level was measured using ELISA methods and Sunlong biotech Rat ELISA Leptin Kit. The procedure of ELISA was based on the procedure assay in manual book.

\section{Analysis of Data}

The results were assayed by SPSS 18. Data was assayed for bivariate and multivariate analysis. Bivariate analysis was used T test and multivariate test was used posthoc test.

\section{Results}


The Efficacy of Seluang Fish Oil on Body Weight, Trigliserida, Adiponectin and Leptin Level

Table 1 showed Seluang Fish Oil fruit extract 0,4 mL/200 gr BW was more potent to reduce body weight gain, trigliserida level, adiponectin and leptin level than Seluang fish oil0,1 $\mathrm{mL} / 200 \mathrm{gr} \mathrm{BW}$, seluang fish oil 0,2 mL/200gr BW, negative control and positive control.

Table 1. The Efficacy of Seluang Fish Oil Fruit Extract on Body Weight, Trigliserida and Leptin

\begin{tabular}{|c|c|c|c|c|c|}
\hline Variable & Group & Before & After & p value ${ }^{*}$ & $\%$ gained \\
\hline \multirow{5}{*}{$\begin{array}{l}\text { Body } \\
\text { Weight } \\
\text { (gram) }\end{array}$} & Negative Control & $220 \pm 5.72$ & $220 \pm 8.83$ & 1.000 & 0 \\
\hline & Positive Control & $221 \pm 7,21$ & $203 \pm 5,23$ & 0.015 & -7.72 \\
\hline & Oil $0,1 \mathrm{~mL} / 200 \mathrm{gr} \mathrm{BW}$ & $222 \pm 6.78$ & $200 \pm 7.82$ & 0.011 & -9.91 \\
\hline & Oil0,2 mL/200 gr BW & $222 \pm 14.9$ & $211 \pm 11.43$ & 0.016 & -4.95 \\
\hline & Oil 0,4 mL/200 gr BW & $224 \pm 11.11$ & $190 \pm 5.72$ & 0.018 & -15.18 \\
\hline \multirow{5}{*}{$\begin{array}{l}\text { Trigliserida } \\
\text { (mg/dL) }\end{array}$} & Negative Control & $212 \pm 6.75$ & $212 \pm 1.09$ & 1.000 & 0 \\
\hline & Positive Control & $213 \pm 5.87$ & $200 \pm 3,76$ & 0.021 & -6.43 \\
\hline & Oil $0,1 \mathrm{~mL} / 200$ gr BW & $221 \pm 6.15$ & $198 \pm 0.53$ & 0.011 & -10.42 \\
\hline & Oil0,2 mL/200 gr BW & $216 \pm 5.65$ & $199 \pm 0.84$ & 0.004 & -7.91 \\
\hline & Oil 0,4 mL/200 gr BW & $215 \pm 5.25$ & $169 \pm 0.78$ & 0.009 & -21.39 \\
\hline \multirow{5}{*}{$\begin{array}{l}\text { Adiponectin } \\
(\mathrm{pg} / \mathrm{mL})\end{array}$} & Negative Control & $78.78 \pm 0.87$ & $78.87 \pm 5.12$ & 1.000 & 0 \\
\hline & Positive Control & $70,65 \pm 1.09$ & $77.35 \pm 5.43$ & 0.013 & 8.67 \\
\hline & Oil $0,1 \mathrm{~mL} / 200$ gr BW & $69.23 \pm 0.34$ & $75.47 \pm 6.22$ & 0.011 & 7.69 \\
\hline & Oil0,2 mL/200 gr BW & $69.13 \pm 0.35$ & $80.45 \pm 5.23$ & 0.003 & 13.75 \\
\hline & Oil 0,4 mL/200 gr BW & $61.23 \pm 0.87$ & $79.17 \pm 6.52$ & 0.008 & 22.78 \\
\hline \multirow{5}{*}{$\begin{array}{l}\text { Leptin } \\
(p g / m L)\end{array}$} & Negative Control & $78.87 \pm 5.12$ & $78.78 \pm 0.87$ & 1.000 & 0 \\
\hline & Positive Control & $77.35 \pm 5.43$ & $70,65 \pm 1.09$ & 0.013 & -8.67 \\
\hline & Oil $0,1 \mathrm{~mL} / 200 \mathrm{gr} \mathrm{BW}$ & $75.47 \pm 6.22$ & $69.23 \pm 0.34$ & 0.011 & -7.69 \\
\hline & Oil0,2 mL/200 gr BW & $80.45 \pm 5.23$ & $69.13 \pm 0.35$ & 0.003 & -13.75 \\
\hline & Oil 0,4 mL/200 gr BW & $79.17 \pm 6.52$ & $61.23 \pm 0.87$ & 0.008 & -22.78 \\
\hline
\end{tabular}

*Paired T test, $\mathrm{p}=0,05$

\section{Discussion}

Seluang fishoil showed dose-dependence efficacy to reduce body weight, leptin,trigliceridaand increase adiponectin level. Seluang fish oil at doses 0,4 mL/200 gr BW had more potent to reduce body weight, leptin,triglicerida and increase adiponectin level than seluang fishoil at doses $0,1 \mathrm{~mL} / 200 \mathrm{gr} \mathrm{BW}$ and $0,2 \mathrm{~mL} / 200 \mathrm{gr} \mathrm{BW}$. The increasing doses of 
extract did not positive correlation with efficacy to reduce body weight, leptintriglicerida and increase adiponectin level. Based on selung fish oil analysis, seluang fishoil contained omega 3 and omega 6 . Fatty acids, omega-3s, are potent fatty acids for prevention and management of obesity. Omega-3 is an essential fatty acid obtained from outside the body, because the body is unable to produce these fatty acids. ${ }^{6,7}$ There are two essential fatty acids, omega 3 and omega 6. Omega 6 is represented by linoleic acid (LA) and omega 3 is represented by alpha-linoleic acid (ALA). LA will be metabolized to arachidonic acid (AA) and ALA will be metabolized to eicosapentaenoic acid (EPA) and docosahexaenoic acid (DHA). EPA and DHA are commonly found in fish oil. ${ }^{8,9}$ Omega 3 will reduce fat decomposition in adipose tissue by suppressing lipogenic enzymes and increasing $\beta$-oxidation. Studies show that EPA and DHA supplementation can prevent obesity, lose weight. Omega 3 will decrease the inflammatory response and decrease the production of prostaglandins and leukotriene, furthermore, will be followed by decreased cytokines TNF alpha and IL-6. Omega 3 also directly affects the expression of the PPAR gen gene, which plays a role in the process of adipogenesis, improves insulin sensitivity and energy restoration. ${ }^{10-12}$

\section{Conclusion}

Seluang fish oil had a potention to reduce body weight, triglyceride,leptin and increase adiponectin level.

\section{Acknowledgments}

We thank to Maisha Pusrita, ST and Supratman for assistence the laboratory process of this research.

\section{References}

1. Auwerx J. PPAR gamma, the ultimate thrifty gene. Diabetologia. 1999; 42(9):10331049.

2. Buckley J.D., Howe P.R. Anti-obesity effects of long-chain omega-3 polyunsaturated fatty acids. Obes. Rev. 2009;10:648-659. doi: 10.1111/j.1467-789X.2009.00584.x. [PubMed]

3. De Gomez Dumm I.N.T., Brenner R.R. Oxidative desaturation of alphalinolenic, linoleic, and stearic acids by human liver microsomes. Lipids. 1975;10:315-317. doi: 10.1007/BF02532451. [PubMed] 
4. Kang J.X. The importance of omega-6/omega-3 fatty acid ratio in cell function. The gene transfer of omega-3 fatty acid desaturase. In: Simopoulos A.P., Cleland L.G., editors. Omega-6/Omega-3 Essential Fatty Acid Ratio: The Scientific Evidence. Volume 92. Karger; Basel, Switzerland: 2003. pp. 23-36. [PubMed]

5. LeBlanc CJ, Horohov DW, Bauer JE, Hosgood G, Mauldin GE. Effects of dietary supplementation with fish oil on in vivo production of inflammatory mediators in clinically normal dogs. Am J Vet Res. 2008;69(4):486-493.

6. Li S, Shin HJ, Ding EL, van Dam RM. Adiponectin levels and risk of type 2 diabetes: a systematic review and meta-analysis. J Am Med Assoc. 2009;302(2):179-188.

7. Simopoulos A.P. Evolutionary aspects of diet and essential fatty acids. In: Hamazaki T., Okuyama H., editors. Fatty Acids and Lipids-New Findings. Volume 88. Karger; Basel, Switzerland: 2001. pp. 18-27.

8. Ukropec J., Reseland J.E., Gasperikova D., Demcakova E., Madsen L., Berge R.K., Rustan A.C., Klimes I., Drevon C.A., Sebokova E. The hypotriglyceridemic effect of dietary $n-3$ FA is associated with increased beta-oxidation and reduced leptin expression. Lipids. 2003;38:1023-1029. doi: 10.1007/s11745-006-1156-z. [PubMed]

9. Wozniak SE, Gee LL, Wachtel MS, Frezza EE. Adipose tissue: the new endocrine organ? A review article. Dig Dis Sci. 2009;54(9):1847-1856.

10. Radin MJ, Sharkey LC, Holycross BJ. Adipokines: a review of biological and analytical principles and an update in dogs, cats, and horses. Vet Clin Pathol. 2009;38(2):136156.

11. Ishioka K, Hosoya K, Kitagawa H, Shibata H, Kimura K, Saito M. Plasma leptin concentration in dogs: effects of body condition score, age, gender and breeds. Res Vet Sci. 2007;82(1):11-15.

12. Verkest KR, Fleeman LM, Morton JM, Ishioka K, Rand J. Compensation for obesityinduced insulin resistance in dogs: assessment of the effects of leptin, adiponectin, and glucagon-like peptide-1 using path analysis. Domest Anim Endocrinol. 2011;41(1):2434. 